\title{
Tijdschrift voor Entomologie 150 volumes: one and a half century of Systematic Entomology in a changing world
}

\author{
Erik J. van Nieukerken \& Hans Huijbregts
}

\begin{abstract}
The Tijdschrift voor Entomologie started in 1857 and 1858 with volume 1, and has now existed for 150 years. A brief history is presented, and details are given on editors (including biographies), composition, publication dates, indexes, authorship, division of articles over biogeographic regions and taxonomic groups, illustrated with graphs and tables. The complete index of 150 volumes is published online at the same time as this issue, as are pdf files of volumes 141 to 148 , and some papers of this issue.

E.J. van Nieukerken* \& J. Huijbregts, National Museum of Natural History

Naturalis, PO Box 9517, 2300 RA Leiden, The Netherlands.

nieukerken@naturalis.nl, huijbregts@naturalis.nl
\end{abstract}

\section{Introduction}

In 2007 this Journal celebrates its 150th volume and its 150th birthday. Although it is not the only journal reaching this age, it is still a rare event amongst entomological journals to publish a volume every year during one and a half century, and without changing its name.

During the 150 years of the journal's existence, society as a whole, science, as well as the entomological community, have changed considerably. Where 150 years ago written media were almost the only way of communication between scientists, as printed publications, or handwritten letters, now the printed media are often considered obsolete, and old fashioned, and communication has been taken over by the new media. The role of paper journals evidently is changing and journals have to adapt to modern ways of communication. The Tijdschrift voor Entomologie (further abbreviated as TvE) is following this trend as well by developing a website (http://www.nev.nl/tve) and providing pdf files of the published papers. The requirements for the validity of species descriptions by the Code (International Commission on Zoological Nomenclature 1999) prevents journals from completely dropping paper publication in favour of web publication, but in other fields of science this is already a fact.

In this paper we will briefly review the history of TvE, particularly with regard to changes in content, with reference to authorship, taxonomic group, topics etc.

At the occasion of the publication of this issue, we also will upgrade the TvE website with the complete index to 150 volumes, and pdf files of several recent volumes. Here we will also present some information on the methods used preparing the index for the website.

\section{Material and methods}

We examined several series of the Tijdschrift voor Entomologie, notably the bound volumes in the library of the National Museum of Natural History (http://212.0.231.237/vubissmart/vubis.csp) and the library of the Netherlands Entomological Society (http://www.nev.nl/catalogus/index.php). We also used our own incomplete series, which are partly unbound and have original covers. Other sources for the journal history are cited throughout the text. 


\section{Index}

The overriding ambition of the project was to make the complete index to TvE available online. This will be presented at the publication date of this issue (1 December 2007) (www.nev.nl/tve).

All articles are in principle covered. The proceedings of the society and most of the appendices to the proceedings are included if they had a separate title. Book reviews are not fully covered.

The index was stored as an EndNote ${ }^{\circledR}$ reference database. The basis for this was formed by three separate databases: first, the database of the library of the NEV that contains many early articles in TvE, entered by Willem Ellis. Secondly, R.M. Biesheuvel (Natuurmuseum Rotterdam) had scanned the table of contents of all volumes in the library of the Rotterdam museum and converted these to text with OCR software for use in their library. Thirdly, we had built an EndNote database from the digitized material of most modern volumes, including abstracts. After combining, these references were edited and several fields standardised. We added information on the language of the paper, the national affiliation of the author, (insect) orders treated and biogeographical region treated. The Netherlands are treated as a separate 'region', and the Palaearctic region excludes articles that are dealing with The Netherlands only. In analyses of articles, page counts include volumes 1-149 and supplement volumes, but are exclusive of the society proceedings.

The finalized database was subsequently converted to Excel sheets for the simple statistic analyses presented here.

\section{Brief history}

The Netherlands Entomological Society, official name "De Nederlandse Entomologische Vereniging" (old spelling "De Nederlandsche Entomologische Vereeniging", further abbreviated as NEV), started informally after an advertisement in a Dutch newspaper at a meeting in Amsterdam, 30 August 1845. The society was finally founded on 12 October 1845 in Amsterdam, with 24 members. Many details about the history of the Society were published in fifty year intervals, unfortunately all in Dutch (Van der Wulp 1895, de Meijere 1947, Ellis 1995).

Discussions on a society journal started soon, and were recorded in the minutes of the general meeting in Utrecht, 5 August 1847. However, financial constraints and the small number of members prevented an early start.

In this period, proceedings of the meetings were published in a cultural weekly magazine, "De Algemeene Konst- en Letterbode" (some volumes can be found on http://books.google.com). Reprints of the proceedings were sent to members and foreign societies. Meanwhile, an editorial committee was elected (consisting of S.C. Snellen van Vollenhoven, J. van der Hoeven and M.C. Verloren), which started to reprint the scientific part of the published meeting reports as a separate journal between 1854 and 1856, the "Handelingen der Nederlandsche Entomologische Vereeniging", but unfortunately without the minutes of the business meeting.

Finally a publisher was found for a journal and the first issues of Volume 1 could be published in 1857. The first issue (and a prospectus) was published both with a French and Dutch title page (French title page, with title "Mémoires d'Entomologie" depicted here on the frontispiece), but the title page of the first volume bears the present name (facsimile on frontispiece in Volume 150: 1). Although the publication year of volume 1 is 1858 , the first few issues were already distributed in 1857 (Barendrecht 1957).

Publication of the journal has continued with only some delay during the years of World War II, when some volumes were postponed one or more years, but finally all volumes have been published, with the result that we now celebrate volume 150 .

Publication has always seen various challenges in a small country with a small entomological community. Financial problems often threatened the continuation, but thanks to grants by the state and several private and governmental foundations, as well as donations by private persons, $\mathrm{TvE}$ could continue to be published.

The first volumes were published by commercial publishers: volume 1 by Martinus Nijhoff (The Hague), volumes 2 to 6 by E.J. Brill (Leiden) for the Society, volume 7 by A.G. Kruseman (Haarlem) and 8-69 again bij Martinus Nijhoff (details see Barendrecht 1957, van der Wulp 1895). Since then TvE was published by the society, although there have been initial negotiations with publishers. The co-operation with Kruseman publishers was an unhappy one: not satisfied with the income, the publisher destroyed the complete stock, making original versions of volume 7 very scarce. This volume was reprinted in 1888 to complete the series for later subscribers.

During the period where the Society was the publisher, the journal was printed respectively by "Drukkerij C. de Boer", in Den Helder (volumes 70, 1928 to $76,1933)$ and from volume 77 (1934) onwards by “Drukkerij Ponsen \& Looyen", Wageningen. In the older volumes the printers' name was printed on the back of the paper volume cover. This information is often lost in bound volumes. 
Table 1. Managing editors of the Tijdschrift voor Entomologie.

\begin{tabular}{lcc} 
Editor & \multicolumn{1}{c}{ Years } & \# years \\
\hline S.C. Snellen van Vollenhoven & $1853-1880$ & 27 \\
F.M. van der Wulp & $1880-1894$ & 14 \\
A.F.A. Leesberg & $1894-1906$ & 12 \\
J.C.H. de Meijere & $1906-1940$ & 34 \\
J.B. Corporaal & $1940-1952$ & 12 \\
A. Diakonoff & $1952-1974$ & 22 \\
P.J. van Helsdingen & $1975-1987$ & 12 \\
J. van Tol & $1988-1997$ & 9 \\
E.J. van Nieukerken & $1989-2007$ & 18
\end{tabular}

\section{Editors}

TvE has always had a board of editors with at least three members, one of whom has acted as managing editor or editor-in-chief (usually as a combined function). In the beginning the number of three was regulated under the bye-laws, which also required that the president of the society was on the board, the other two being elected by the members. At some point in history, this was changed and editors were elected by the board and not by the members any more. For the majority of volumes, it is easy to find out who were on the board, because they were listed on the covers. However, from volume 96 (1953) to 109 (1966), the covers mentioned all members of the editorial committee, that together edited all three journals of the society. It is therefore not always easy to find out who edited TvE, even more so, because some served both on the board for $\mathrm{TvE}$ and the Entomologische Berichten. We will provide a list of editors, with active years, on our website, with uncertainties added. This will be updated when more information becomes available.

The covers did not usually mention who was the managing editor or editor-in-chief. For the first hundred years Barendrecht (1957) provided the names of the persons he considered to be the acting managing editors. Later these editors were better indicated in print, and also known to us personally (see Table 1). It is evident that de Meijere served longest with 34 years, followed by Snellen van Vollenhoven and Diakonoff. From 1989-1997 van Tol and van Nieukerken served together as managing editors.

At the end of this paper we provide brief curricula and photographs of these managing editors.

The Journal was first based in the old "'s Rijks Museum van Natuurlijke Historie" where Snellen van Vollenhoven was curator, then a group of entomologists in The Hague formed the core of editors (apart from the managing editors, P.C.T. Snellen and
E. Everts belonged also to this group), and in the period 1906 to 1952 it was based in the Zoological Museum of Amsterdam, to return to Leiden when Diakonoff became editor-in-chief. This situation has remained the same to the present.

A major change in the editorial board, however, occurred in 2005 (volume 148) when five foreign entomologists joined the editorial board to strengthen the international standing of the journal.

Editorial work remained relatively unchanged until the late eighties in the $20^{\text {th }}$ century: corresponding with authors, checking manuscripts, making editorial notes and sending the accepted manuscript to the printers. The printers did all the technical work to prepare the printed texts. These things changed dramatically during the 1990's: first the printers Ponsen \& Looyen started to use Macintosh computers to replace the older page formatting systems, making it much easier to send in digitised manuscripts, which - although possible for some years - was still cumbersome and needed a lot of cryptic coding. The change can be seen in the slight change of type face from volume 135 to 136 (1993), the latter being type set on an Apple Macintosh computer with Quark XPress ${ }^{\circledR}$ page formatting software. When such computers also entered the museum, the possibility to do part of the type setting directly, made it possible for editors to control the lay-out in more detail and to avoid many errors having to be corrected afterwards. Gradually during the 1990's, the lay-out was no longer made by the printers, but for several years the editors prepared the lay-out, first of text only - with scanning of illustrations still carried out by the printers - later, a fully page formatted set was sent to the printers directly. Page formatting and lay-out is now outsourced with Mrs. Maria Schilder (Amsterdam), also responsible for the new lay-out and the covers.

Another big change that computers brought was the rapid communication. Gradually letters were replaced by e-mail, and now everything is done via e-mail, including submission, sending manuscripts to reviewers, sending material to type setter, sending to printers, and sending proofs. The authors now receive their pdf's on the day of publication. Postal mail is hardly used any more, except for sending the journal to subscribers and reprints to authors!

\section{Composition and publication dates}

TvE was always published in a number of issues, although a few issues, particularly after WW II, were published as single issues (vols. 85-93). The first 19 volumes consisted in principle of six issues each (Barendrecht 1957), of which the exact contents cannot be reconstructed from bound volumes, nor from copies kept in wrappers. Probably a number of 
Figs 1-8. Covers of various issues of the Tijdschrift voor Entomologie. - 1, Volume 14 (1871); 2, volume 39 (3-4), 1896; 3, volume 69 (1), 1926; 4, volume 86, 1944 [1943]; 5, volume 100 (1), 1957; 6, volume 129 (2), 1986; 7, volume 148 (2), 2005; 8, volume 150 (1), 2007.

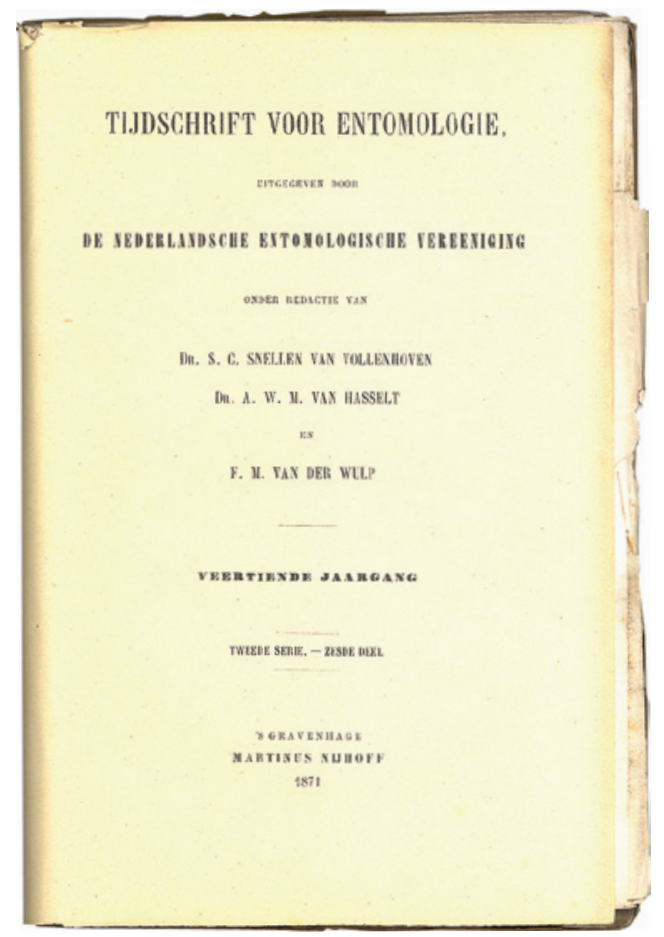

TIJDSCHIIIFT VOOR ENTOHOLOGIR

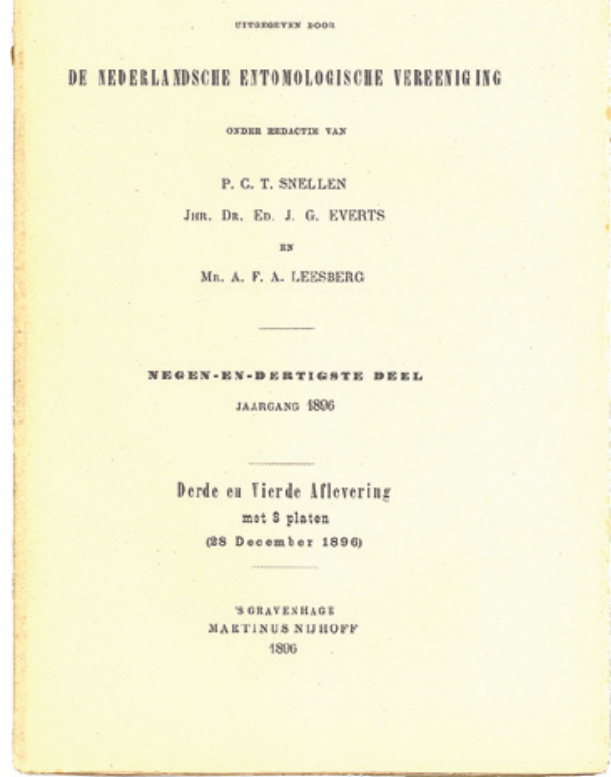

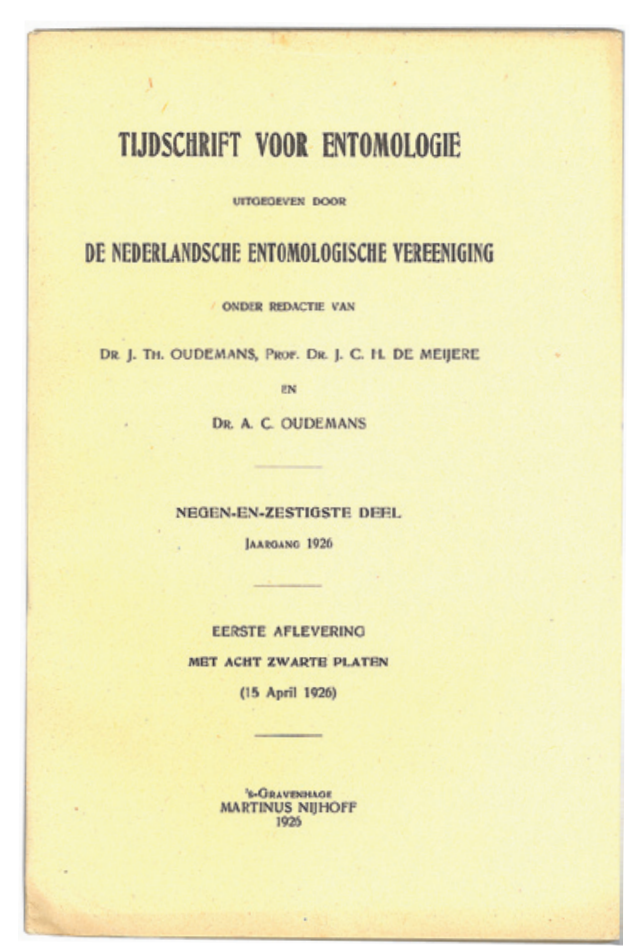

\section{Tijdschrift voor Entomologie}

UTGEGSVEN DOOR

\section{De Nederiandsche Bntomologische Vereeniging}

$$
\text { ONDER REOACTE VAN }
$$

DR. D. MAC GILAVRY, J. B. CORPORAAL,

J. J. DE VOS TOT NEDERVEEN CAPPEL.

E G. L. VAN EYNDHOVEN.

\section{ZES-EN-TACHTIGSTE DEEL.}

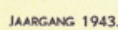

(Gepulliveed? Aperil 1944) 


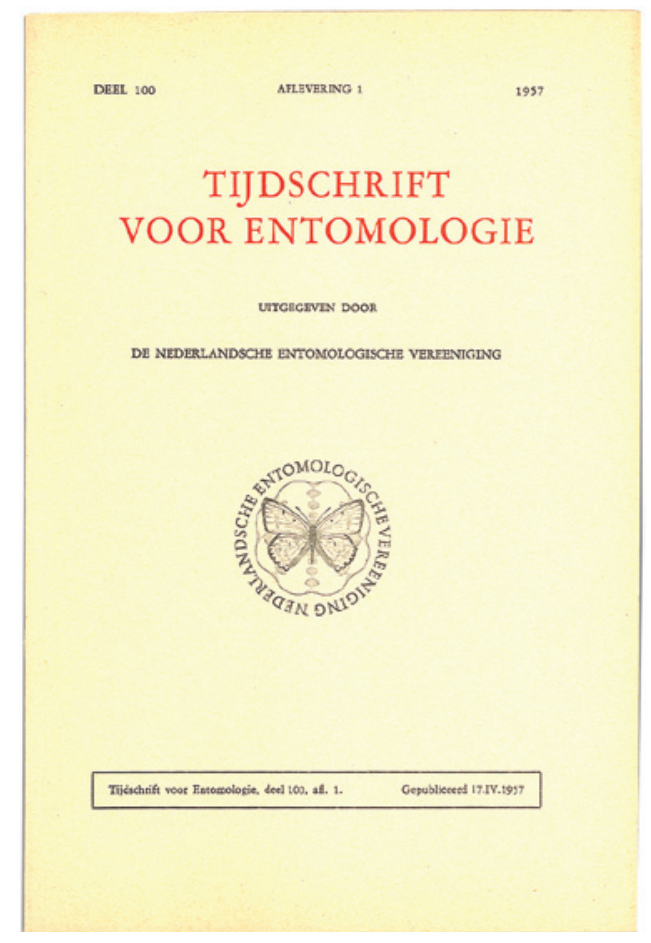

DEEL 129

\section{TIJDSCHRIFT \\ VOOR ENTOMOLOGIE}

UTTGLGEVEN DOOR

DE NEDERLANDSE ENTOMOLOGISCHE VERENIGING

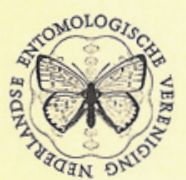

INHOUD

THoven PAPE. - A phylogenecic analysis of the Woodlowse-fies (Diptera, Rhinophoridae), pp. 15-34, figs. $1-30$.

Tijhechritt roor Enecenolopie, ded 129, Hi. 2 Gespubliceerd 10.X1-1986

Volume 148, no. 2, 2005

Tijdschrift

voor

Entomologie

A journal of systematic and evolutionary entomology since 1858 $\frac{1}{3}(x)=$

A journal of systematic and evolutionary entomology since 1857

Tijdschrift voor Entomologie

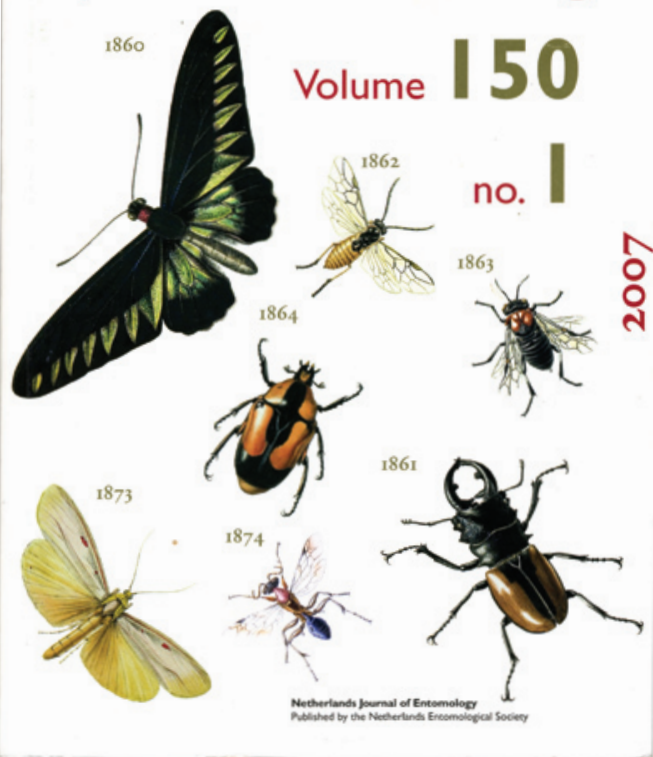




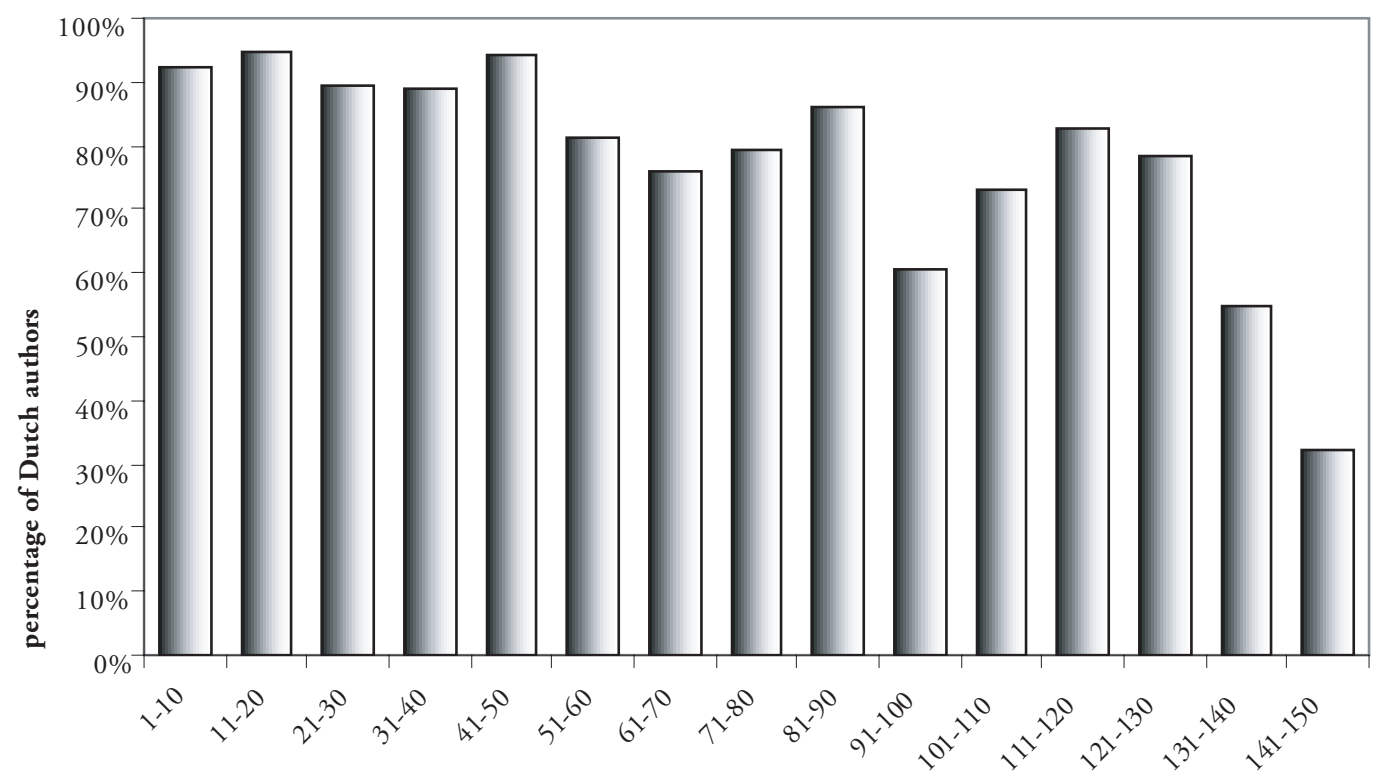

volumes

Fig. 9. Percentage of papers where the senior author has the Netherlands' nationality or when not, is working and living in The Netherlands.

separate quires and plates were sent in each delivery. Only for volume 1 we know from meeting reports and original copies, kept in the NEV library, that issue $1-3$ contained pages $1-24$, which were distributed in 1857.

From volume 19 (1876) until 103 (1960), a single volume comprised in principle four issues, although often combined as issues 1-2 and/or 3-4 or in other combinations. Volumes 19 to 37 were probably still sent out as a number of quires, although in one of our sets $(\mathrm{EvN})$, we have a bound second issue of vol. 29 with covers (1886, pages xciii-cviii, 33-112, pls. 1-2). Because of the way they were published, the publication dates of these first 37 volumes are not always exactly known.

As it is important to know exact publication dates to establish priority of names and other nomenclatorial acts, we have spent some time to reconstruct the exact publication dates. Barendrecht (1957) provided an estimate of publication times, based on the communications published in the proceedings. However, there are still many questions around publication dates and pagination of the issues in volumes 1-18.

From volume 38 on, issues were bound, with covers, mentioning issue numbers and publication dates, and no more problems exist as to dating individual papers.

The publication of issues with several papers was discontinued in volumes 104 (1961) to 129 (1986), when each issue contained a single paper, and a number of issues were published on the same date. A clear disadvantage was that short papers could no longer be accommodated. This changed again and volume 130 (1987) was published as a single issue and from then on there have been two issues annually, in principle published on the $1^{\text {st }}$ of June and the $1^{\text {st }}$ of December. A few times these dates were not met, but since 2001 (vol. 144) all issues were published on time.

A list with publication dates and pagination of volume $1-150$, as detailed as currently known, can be downloaded from our website (www.nev.nl/tve).

At the end of each year, until volume 132, a cover for the volume was sent to the subscribers, together with the contents of that volume. From volume 25 onwards, also an annual index to all treated taxa was included. Before that, three indexes ("Repertorium") for eight volumes each have been published as separate books (de Roo van Westmaas 1869, van der Wulp 1875, 1882). From volume 133 onwards, the annual index was printed at the end of the second 


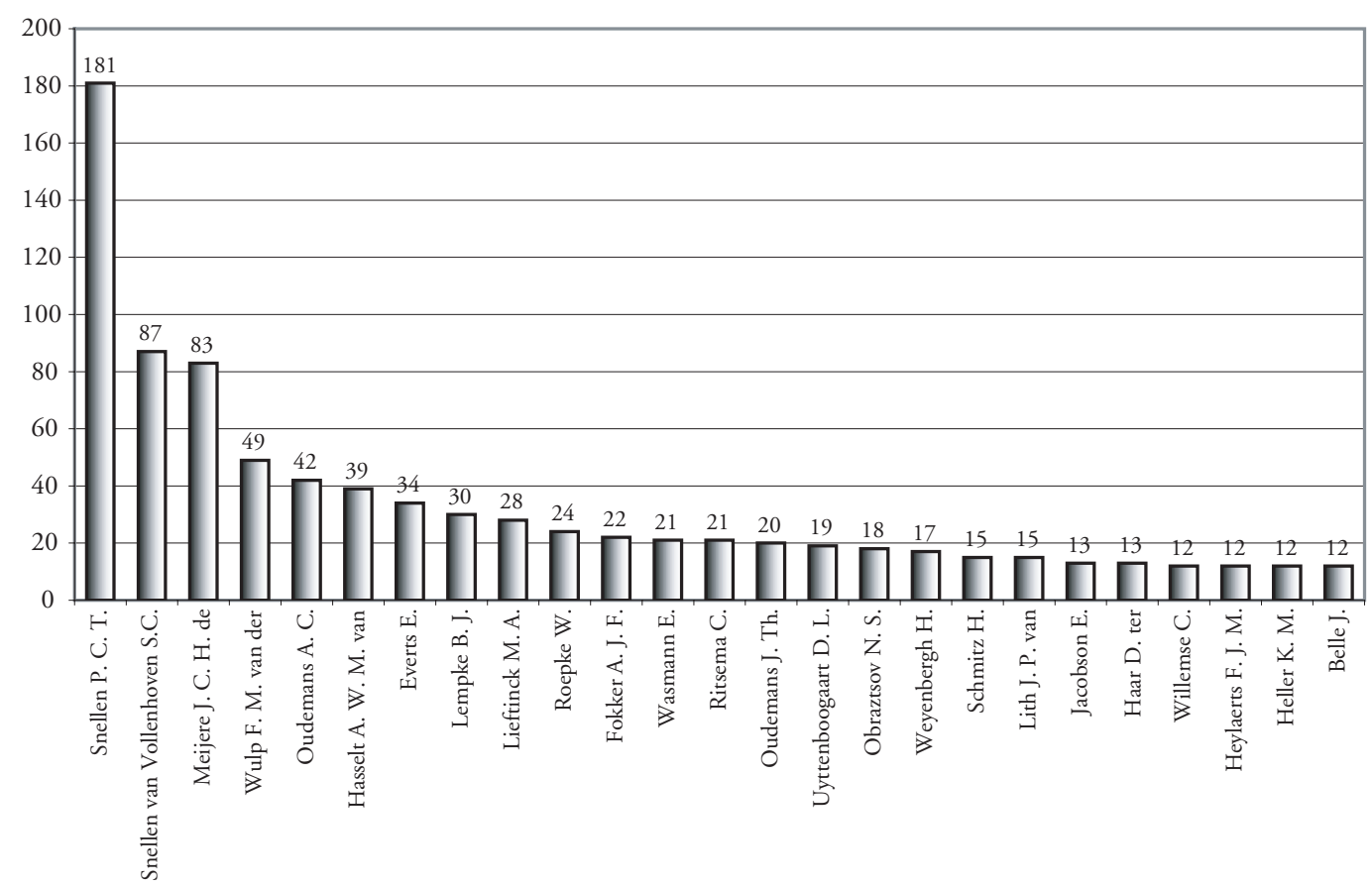

Fig. 10. Total number of papers published in TvE by 25 top authors as single author. Co-authored papers and contributions in proceedings are not included.

issue, as pages i-viii (or vii), with the alphabetic list of papers and a list of new taxa.

\section{Supplements}

In the course of the journal's history a few supplements have also been published, all with separate pagination. They were published to accommodate a single large monograph, such as a Diptera catalogue (van der Wulp \& de Meijere 1898), or the very extensive historical survey of Acari, published in two years (Oudemans 1926, 1929a, 1929b, 1929c). A third volume for that series was finally published elsewhere (in six parts). Other supplements were a celebratory volume, such as volume 75 to honour the $70^{\text {th }}$ birthday of J. Th. Oudemans. Supplements to volumes 56, 58, 62 and 67 were externally financed and all contain papers on the insect fauna of the Dutch East Indies. After volume 75, no more supplements have been published, and during the 1960's a new journal, "Monografieën der Nederlandsche Entomologische Vereeniging", was established to accommodate larger monographs. These monographs used to be edited by the TvE editors as well. All these monographs are still available at the society (http://www.nev.nl/ mono.html)

\section{Lay-out}

The lay-out of $\mathrm{TvE}$ has always been somewhat formal and serious, as is appropriate for scientific journals. Studying various volumes, one will notice that the journal remained much the same until 1952, with some changes in type face and headings. Usually the text was in one column and headings centered. In the $19^{\text {th }}$ century all plates were still separate as (often hand coloured) lithographs or engravings (see also Schilthuizen on pages 263-269), in the $20^{\text {th }}$ century illustrations started to appear in the text and plates were usually black and white, including photographs. The covers also changed very little as can be seen in some examples in Figs 1-8.

A great change was introduced when Diakonoff became new editor: he restyled the journal, and on the cover used the new logo that was specially made on the occasion of the International Entomological Congress in Amsterdam in 1951 (Figs 5, 6). This logo, designed by Pieter Wetselaar, shows the endemic subspecies of the large copper, Lycaena dispar batavus (Oberthür, 1923), on top of its greatly enlarged egg. The logo is still printed on each issue. When printing costs were rising again, the style of the journal was changed into a two column lay-out from vol. 125 (1982) to save space. 


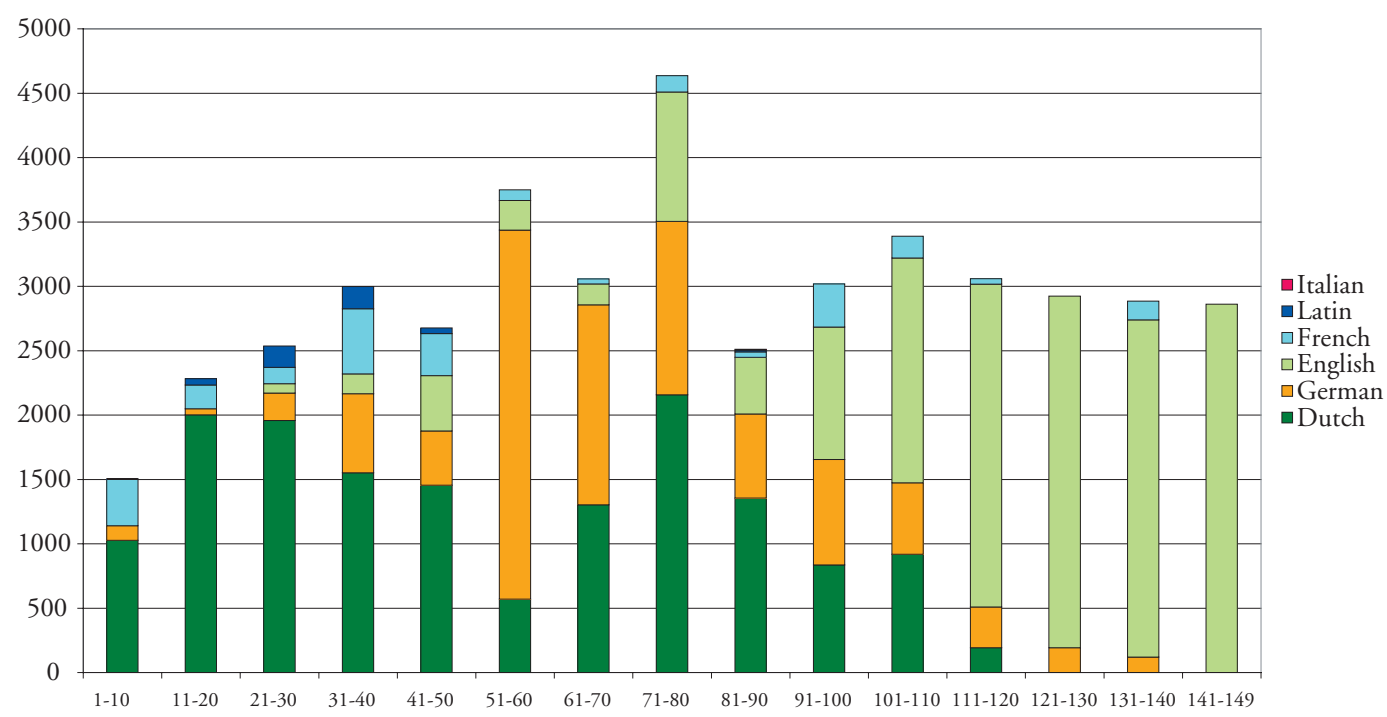

Fig. 11. The number of pages of scientific papers per language per decade.

A next great change was the modernisation of the journal in 1990 (vol. 133). This followed the advise by a committee (Duffels, Ulenberg, van Tol) that reported to the board of the NEV about the future possibilities of $\mathrm{TvE}$, when financing had become tight, and the number of subscribers very low. Their recommendation was to internationalise the journal and restyle it at the same time. Van Tol and van Nieukerken, who have jointly edited the journal between 1989 and 1997, approached a professional designer (Aad Derwort) and asked for a complete new design, and the one chosen was a purple cover with a varnish layer based on an old plate with various insects depicted (Fig. 7). The contents pages and inside cover were also greatly modernised, as well as many editorial matters. This lay-out was well received, but this year we considered that after 17 years the time is ripe for another modernisation, of which you can see the results in this issue. The covers of volume 150 were specially designed for this year.

\section{Publication medium for scientific articles}

In the first 44 years of its existence, TvE was the only Dutch journal completely devoted to entomology. In 1901, upon request from members for a simpler and more frequent journal, the Entomologische Berichten (EB) was established. This journal appeared more frequently and especially accomodates smaller articles and informal short notes. In contrast to TvE, all members received $\mathrm{EB}$ and they still do, whereas the subscription to TvE has always been optional.

Although TvE had a rather broad scope in the first half of the 20th century, it still was mainly a taxonomic and faunistic journal.

Applied entomology was rapidly growing and becoming a separate discipline, following the economic growth in the world, amongst others resulting in massive insect pests, use of pesticides and health campaigns against diseases such as malaria. On the initiative of P. van der Laan, a third society journal, Entomologia Experimentalis et Applicata, devoted to applied entomology, was first published in 1958. This journal has always been published commercially and has grown into an influential journal in the field of applied entomology (currently published by Blackwell for the NEV, see http://www. blackwellpublishing.com/journal.asp? ref=00138703\&site $=1$ ).

After restyling the journal in 1953, it also started to become a more international venue and Diakonoff managed to attract an increasing number of foreign authors. As stated above, a further step towards internationalisation was made with vol. 133, when Dutch was almost entirely dropped, and a more international authorship was invited to contribute. Before that the share of Dutch authors in TvE had always been large; in the last two decades however the Dutch contributions have fallen sharply to less than 30\% (Fig. 9). This follows the internationalisation, and the agreement with the editors of EB to 


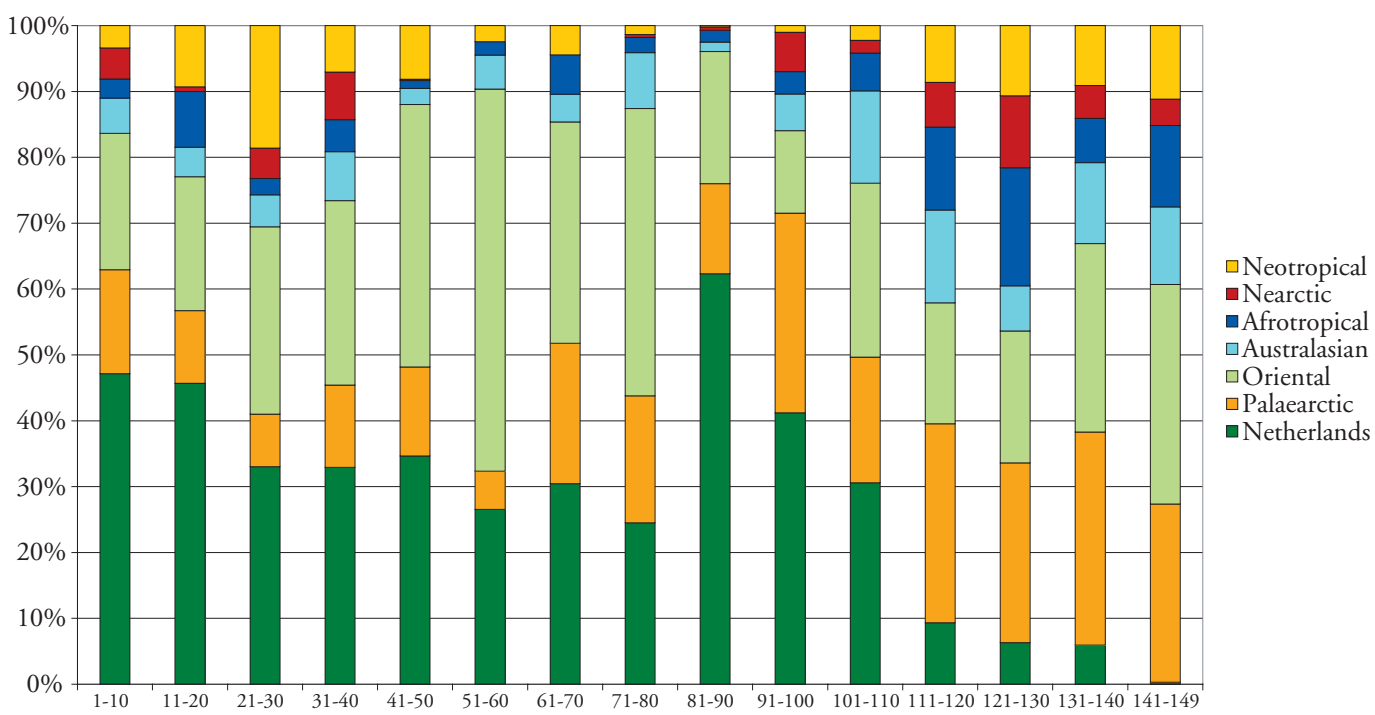

Fig. 12. Distribution of scientific articles over biogeographic regions, as percentage of total pages.

place mainly faunistic articles in EB, at the same time that there exists a wider choice in journals devoted to faunistics.

\section{Proceedings of the society}

Publishing the proceedings was one of the first reasons to establish the journal. During the first 95 volumes the proceedings of the society were both published in TvE, and separately for the society members that did not subscribe, sometimes even with a pagination different from that in the journal. Apparently these separately printed proceedings were dispatched earlier than the issues of the journal, so they often have priority over the issues of the journal. Proceedings were usually paginated with Roman numerals, but in several volumes Arabic numerals were used both for the proceedings and for the articles, leading to confusion. For citation purposes one should add 'verslag' (= proceedings) to the pagination of such proceedings to avoid confusion. The main content of the proceedings consisted of proceedings of the meetings, membership lists, lists of additions to the library and results of excursions. The most frequently cited parts are the scientific contributions by members attending the meetings. As in many other journals, these reports are bibliographically a problem, but very often contain original scientific contents, often published prior to the journal article devoted to the same subject. This can be especially problematical in the case of nomenclatorial acts. Occasionally new species were even described in the proceedings, either in the main text or in appendices. The early proceedings are a bibliographic nightmare (Mac Gillavry 1932, 1933).

\section{Means of exchange for the library}

It has been a long tradition amongst learned societies and libraries of museums and the like, to exchange each others publications without further costs. In this way libraries easily build on their journal collection. This is one of the reasons to maintain journals, and the society normally contributes a fixed sum to the costs of the journal as payment for these copies. This is currently still the situation for TvE, EB and many similar journals. Almost certainly with the change in publication from paper towards electronic media, this policy will also change.

\section{Authors}

In the database of regular articles (excluding proceedings), we note 699 author or author combinations for a total of 2115 papers and 44,088 pages. Of these, 466 authors (or combinations) published only one paper. Only 35 authors (or combinations of authors) published 10 or more articles. We haven't combined scores for single authors and the same authors as co-author with others. With this in mind, we present in Fig. 10 the top 25 authors for TvE.

The top author was P.C.T. Snellen (see Fig. 10): he published 181 papers alone (2479 pages), and 
Table 2. Percentage of total pages per decade, devoted to six insect orders and Arachnida (including Acari). Page count is inclusive of supplement volumes but exclusive of proceedings. Highest percentages for a decade are shaded.

\begin{tabular}{lccccccc} 
Volumes & Lepidoptera & Coleoptera & Diptera & Hymenoptera & Hemiptera & Arachnida & Odonata \\
\hline $1-10$ & 40 & 12 & 9 & 26 & 6 & 4 & 1 \\
$11-20$ & 38 & 6 & 19 & 16 & 17 & 5 & 1 \\
$21-30$ & 39 & 23 & 12 & 8 & 6 & 10 & 0 \\
$31-40$ & 36 & 28 & 6 & 7 & 1 & 12 & 0 \\
$41-50$ & 39 & 12 & 21 & 10 & 2 & 14 & 4 \\
$51-60$ & 9 & 15 & 48 & 11 & 10 & 9 & 2 \\
$61-70$ & 19 & 17 & 26 & 1 & 2 & 20 & 9 \\
$71-80$ & 10 & 25 & 19 & 4 & 9 & 27 & 6 \\
$81-90$ & 33 & 20 & 16 & 20 & 8 & 7 & 2 \\
$91-100$ & 42 & 14 & 15 & 18 & 12 & 9 & 0 \\
$101-110$ & 42 & 11 & 6 & 13 & 10 & 5 & 3 \\
$111-120$ & 27 & 2 & 5 & 33 & 6 & 9 & 7 \\
$121-130$ & 24 & 3 & 12 & 41 & 7 & 1 & 7 \\
$131-140$ & 14 & 9 & 18 & 5 & 23 & 7 & 10 \\
$141-149$ & 17 & 8 & 17 & 1 & 30 & 1 & 11 \\
\hline Total & 27 & 14 & 17 & 13 & 10 & 10 & 4
\end{tabular}

another 29 as co-author. Snellen was both active in the faunistics of Dutch Lepidoptera and as taxonomist of global Lepidoptera, with an emphasis on the Dutch East Indies (Piepers 1912). He named 1065 taxa of Lepidoptera (species and genera) according to the Global Lepidoptera database (Beccaloni et al. 2005). Snellen was very devoted to this journal, for which he was one of the editors and at the same time he was president of the society. Snellen rarely published elsewhere, best known are his books on the Dutch Lepidoptera (e.g. Snellen 1882) and Rhopalocera of Java (Piepers \& Snellen 1910-1913).

The first editor Snellen van Vollenhoven is second most productive author, although he wrote less than half the number of papers by Snellen: 87 papers in 1302 pages.

It can be further noted that the top nine authors were all active as editor at some point in time. The most recent authors amongst these 25 were B.J. Lempke, who published his last paper (catalogue of the Dutch Macolepidoptera) in 1970, and Jean Belle, working on Neotropical Odonata, whose last paper was published in 1990. Obraztsov is the first foreigner in this list. Nowadays, such high numbers will no longer be found, because almost all authors spread their publications over a larger number of journals.

\section{Language}

As shown in Fig. 11, the language of the articles in $\mathrm{TvE}$ has changed drastically in the course of time. During the first 50 years most articles in $\mathrm{TvE}$ were published in Dutch. Although the first three issues of volume 1 were also published with French covers, this language never played an important role in TvE. The second period of fifty years was dominated by German, with a sharp fall after WWII. English took over very fast, to the situation now, in which $\mathrm{TvE}$ is an journal exclusively published in English. The last year that a paper in another language was published (French) was 1998 (Terzo \& Rasmont 1998).

\section{Country}

During his long history, TvE has developed from almost exclusively Dutch to a truly international journal. Especially in the first fifty years only authors from a very limited number of countries published in $T v E$. In volumes $141-150$ we find contributions of authors from 30 different countries. In recent years we have seen especially an increase in authors from Japan, with 17 papers since 2000 to become the second country after The Netherlands (with 35 papers).

\section{Biogeographic region}

Figure 12 shows the distribution of biogeographical regions treated in the articles per decade. Because many faunistic articles were exclusively devoted to material from the Netherlands, this country is coded as a separate area. The search engine on the website can make selections based on region. Because The Netherlands is treated as a separate 'region' a search on the Palaearctic region gives only the articles that 
Table 3. Total number of papers per taxonomic group in 149 volumes of TvE. Groups arranged in systematic order.

\begin{tabular}{lr} 
No taxonomic group & 48 \\
Combinations of orders & 64 \\
& \\
other arthropods & 3 \\
Pycnogonida & 133 \\
Arachnida & 10 \\
Myriapoda & 2 \\
Crustacea & \\
& \\
hexapods & 7 \\
Collembola & 3 \\
Thysanura & 5 \\
Ephemeroptera & 58 \\
Odonata & 3 \\
\hline Plecoptera & 56 \\
Orthoptera & 17 \\
Dictyoptera & 2 \\
Dermaptera & 1 \\
Embioptera & 3 \\
Psocoptera & 14 \\
Phthiraptera & 6 \\
Thysanoptera & 184 \\
Hemiptera & 5 \\
\hline Neuroptera & 2 \\
Raphidioptera & 353 \\
Coleoptera & 38 \\
Trichoptera & 594 \\
Lepidoptera & 2 \\
Mecoptera & 13 \\
Siphonaptera & 8 \\
Diptera & 205 \\
\hline Strepsiptera & \\
Hymenoptera & \\
\hline & \\
\hline
\end{tabular}

Total articles

2114

include material from the Palaearctic region, but excludes articles that are treating Dutch material only. Dutch entomologists have always strongly focused their studies on the Palaearctic region (including the Netherlands) and South-east Asia. During the first eleven decades TvE still had a large proportion of papers devoted to The Netherlands; later this shifted more to the West Palaearctic region in general (i.e. outside the Netherlands). The attention for South-east Asia is largely a result of the Dutch colonial past. Although the Netherlands did possess colonies in the Neotropical region, Dutch entomologists did not publish much on that region. Only relatively recently more articles about the New World and the
Afrotropical region are being published in TvE. This also followed a change in editorial policy: from volumes 133 to 141 we had a preference for papers on the Palaearctic and Oriental regions, from volume 142 on this preference was dropped.

\section{Taxonomic groups}

Table 2 shows the number of papers per taxonomic group during 15 decades, order for insects and higher taxon (e.g. Class) for other arthropods. There is a positive correlation between size of taxon and number of papers, but the high number of Lepidoptera (594 papers) is apparent. We expect that this effect can be seen in many similar journals: attention for Lepidoptera has always been high among amateur entomologists in particular, and the top author Snellen was a lepidopterist. It is also apparent that the expertise of the editor had some effect on these numbers. After the period of Snellen van Vollenhoven and Snellen, with a continuous proportion of more than $35 \%$ of papers devoted to the Lepidoptera, there was a distinct drop to less than $20 \%$ in favour of Diptera (editor De Meijere!) and from 1928-1937 Arachnida. This last figure was entirely the merits of A.C. Oudemans, who wrote - next to many other papers - a four volume work on Acari in three supplements with hundreds of pages (Oudemans 1926, 1929a, 1929b, 1929c). After that the proportion for Lepidoptera increased again, particularly when the lepidopterist Diakonoff took over as editor, and due to the multi-part work by Barend J. Lempke: the catalogue of Dutch Macrolepidoptera. After Diakonoff's retirement it dropped again in favour of Hymenoptera (papers by van Achterberg and van Lith). In the last two decades the influence of the editors is less visible, although the number of Odonata papers increased (van Tol's group). By far most papers in the last twenty years are devoted to Hemiptera. Three groups of students are responsible for this: the Cicada working group in the Amsterdam museum around J.P. Duffels, then a growing number of papers on aquatic bugs by N. Nieser, P.-p. Chen, D. and J. Polhemus and H. Zettel, and finally a group of Japanese authors working on terrestrial Heteroptera.

Another way of looking at the dates is presented in Table 3, where we give the number of new taxa published during the last 10 years (total 567). This could be easily compiled from the lists published annually, for the complete journal it is not yet feasible. It shows also that most new taxa were Hemiptera, followed by Diptera, Trichoptera, and Lepidoptera. Striking is the low number of Hymenoptera: just one species. 
Table 4. Number of new species and genera per order described in the last ten volumes, arranged according to decreasing total number.

\begin{tabular}{|c|c|c|c|c|c|c|c|c|c|c|c|}
\hline Order & $\begin{array}{r}\text { Volume } \\
141\end{array}$ & 142 & 143 & 144 & 145 & 146 & 147 & 148 & 149 & 150 & Total \\
\hline Hemiptera & 6 & 46 & 40 & 11 & 14 & 14 & 52 & 16 & 2 & 23 & 224 \\
\hline Diptera & 18 & 3 & 15 & 4 & 10 & 30 & 2 & 20 & 3 & 9 & 114 \\
\hline Trichoptera & & 17 & & 5 & 40 & 1 & & & & & 63 \\
\hline Lepidoptera & 9 & 3 & 6 & 1 & 2 & 5 & 9 & 13 & 5 & 3 & 56 \\
\hline Coleoptera & 3 & & 10 & & & 3 & & & 10 & 21 & 47 \\
\hline Orthoptera & 9 & & & 2 & & 1 & 13 & & & 3 & 28 \\
\hline Odonata & & & 9 & & 5 & 1 & & & 2 & & 17 \\
\hline Acari & & & & & & & & & 4 & 2 & 6 \\
\hline Ephemeroptera & & & & & & & 6 & & & & 6 \\
\hline Strepsiptera & & & & 2 & & & & & & & 2 \\
\hline Neuroptera & & & & & & & 1 & & & & 1 \\
\hline Plecoptera & & & & 1 & & & & & & & 1 \\
\hline Hymenoptera & & & & & & & & & 1 & & 1 \\
\hline Thysanoptera & & & & & & & 1 & & & & 1 \\
\hline
\end{tabular}

\begin{tabular}{llllllllllll}
\hline Total & 45 & 69 & 80 & 26 & 71 & 55 & 84 & 49 & 27 & 61 & 567
\end{tabular}

\section{Scientific importance}

Taxonomy and faunistics have always been the main subjects in TvE, although only from volume 132 this was clearly stated in the subtitle: "A journal of systematic and evolutionary entomology since 1858 " [now changed into 1857]. The scope was formalised on the cover from volume 133:

“The 'Tijdschrift voor Entomologie' (Netherlands Journal of Entomology) has a long tradition in the publication of original papers on insect taxonomy and systematics. The editors particularly invite papers on insect and arachnid taxonomy, especially those including evolutionary aspects e.g. phylogeny and biogeography, or ethology and ecology as far as meaningful for insect taxonomy."

Before the start of Entomologia Experimentalis et Applicata, also some applied and experimental studies were published in TvE, although never many. A special case was the publication of the proceedings of a session in the International Congress of Entomology in Amsterdam (1951) on the symbiosis in insects. This was published in vol. 95 (1-2), and included papers by renown authors such as Wigglesworth and Grassé.

In general, TvE was and is a medium for traditional thorough taxonomy and has never been revolutionary. It is hard to find any reference to the work of Darwin in the first 50 volumes, and modern biogeography and cladistics entered TvE relatively late. A first kind of evolutionary tree was published by Cobben (1970) and the first modern paper on biogeography was by De Jong (1972). In recent years, however, papers in TvE follow modern directions of phylogenetic studies, and also include theoretical papers (Huelsenbeck 2001) and molecular studies (Douroupi et al. 2001 and De Jong in this issue).

The main subject is taxonomy, and it is here that TvE has the greatest impact, although this is not the sort of 'impact' that ISI considers. Taxonomic descriptions are cited long afterwards, and papers in TvE remain cited for a long period. Table 4 shows that in the last ten years no less than 567 new species and genera were described, and when multiplying with 15 (to make up for the 150 years) can be used as a rough estimate of the total, at least 8500 species and genera have been newly described in TvE. We suspect that it is more, and further thousands of species have been redescribed, diagnosed, keyed, biologies provided, etcetera.

\section{The future}

We strongly believe that access to taxonomic papers should be open and long lasting. With the celebration of 150 volumes of TvE, we start to publish pdf's of recent papers on our website, to start with volumes 141 to 148 . For now we will add pdf's with a delay of two years. An ideal would be to have all old volumes online as well. There have been discussion going on, but currently international initiatives, such as the Biodiversity Heritage Library (http://www. biodiversitylibrary.org/) and national initiatives in the Netherlands to scan old journals are taking the lead and we will try to have TvE selected for scanning by one of these projects. Currently some old volumes of $\mathrm{TvE}$ are already available via Google books (http://books.google.com), and some can be 
downloaded, including volume 1 , but searching is cumbersome, and the quality of the scanning work is poor. Also the copy used does not have hand coloured plates.

\section{Acknowledgements}

We would first like to thank Oscar Vorst for all his work to bring the database online and preparation of php query scripts; further we acknowledge his continuous support, also as publisher of the Society. We are grateful to the other members of the editorial board for discussions and advise on this paper.

We thank Willem Ellis for making available the records from the library catalogue, and R.M. Biesheuvel (Natuurmuseum Rotterdam) for making available his complete database of references. Erikjan Rijkers assisted with scripts for conversion and cleaning up text, and Godard Tweehuyzen and Danny Boomsma of the library of the NEV were always ready to send us copies or scans of papers or illustrations.

Jan van Tol, Rienk de Jong, Mike Wilson and Menno Schilthuizen are acknowledged for comments on the manuscript.

\section{References}

Barendrecht, G., 1948. In memoriam Prof. Dr. J.C.H. de Meijere. - Vakblad voor Biologen 28 (1): 1-3.

Barendrecht, G., 1957. A propos du centenaire du Tijdschrift voor Entomologie. - Tijdschrift voor Entomologie 100 (1): 1-4.

Barendrecht, G. \& G. Kruseman, 1949. In memoriam Prof. Dr. J.C.H. de Meijere 1 April 1866 - 6 November 1947. - Tijdschrift voor Entomologie 90: 1-15.

Beccaloni, G., M. Scoble, G. Robinson \& B. Pitkin, 2005. The Global Lepidoptera names index. - Natural History Museum. http://www.nhm.ac.uk/researchcuration/projects/lepindex/index.html [visited on: 2007-10-29].

Cobben, R. H., 1970. Morphology and taxonomy of Intertidal Dwarf-bugs (Heteroptera, Omaniidae fam. nov.). - Tijdschrift voor Entomologie 113 (2): 61-90.

Douroupi, T., O. Konstandi, J. Kathirithamby \& L.H. Margaritis, 2001. Histochemical and molecular evidence of peroxidase activity in Segestidea novaeguineae (Brancsik) (Orthoptera) and Stichotrema dallatorreanum Hofeneder (Strepsiptera). - Tijdschrift voor Entomologie 144 (2): 197-202.

Ellis, W.N., 1995. De Nederlandse Entomologische Vereniging van 1945 tot 1995. - In: P. Koomen, W.N. Ellis \& L.P.S. van der Geest (Eds.), Insekten onderzoeken, een overzicht van vijftig jaar entomologisch onderzoek in Nederland. 189-196. Nederlandse Entomologische Vereniging, Amsterdam.

Everts, E., 1907. In memoriam Mr. A.F.A. Leesberg. - Tijdschrift voor Entomologie 50 (2/3): 117-120.
Helsdingen, P. J. van, 1990. Alexey Diakonoff 1907-1989. - Entomologia Gallica 2: 21-22.

Helsdingen, P. J. van \& E. J. van Nieukerken, 1989. Alexey Diakonoff 1907-1989. - Tijdschrift voor Entomologie 132 (2): 161-162.

Holthuis, L.B., 1995. 1820 - 1958: Rijksmuseum van Natuurlijke Historie. - Nationaal Natuurhistorisch Museum, Leiden. 172 pp.

Huelsenbeck, J.P., 2001. A Bayesian perspective on the Strepsiptera problem. - Tijdschrift voor Entomologie 144 (2): $165-178$.

International Commission on Zoological Nomenclature, 1999. International Code of Zoological Nomenclature. Fourth edition. - The International Trust for Zoological Nomenclature, London. xxix + 306 pp.

Jong, H. de, 2000. The types of Diptera described by J.C.H. de Meijere. - Backhuys publishers, Leiden. $271 \mathrm{pp}$.

Jong, R. de, 1972. Systematics and geographic history of the genus Pyrgus in the Palaearctic region (Lepidoptera, Hesperiidae). - Tijdschrift voor Entomologie 115 (1): $1-121$.

Krikken, J., C. van Achterberg, P.H. van Doesburg, R. de Jong \& K.W.R. Zwart, 1981. Samuel Constant Snellen van Vollenhoven (1816-1880) and his entomological work. - Tijdschrift voor Entomologie 124 (6): 235-268.

Mac Gillavry, D., 1932. Kort overzicht over de wijze van publiceering der Verslagen van de Vergaderingen der Ned. Ent. Ver. (Bibliograpische bijdrage IV). - Tijdschrift voor Entomologie 75 (Suppl.): 229-232.

Mac Gillavry, D., 1933. Bibliographische bijdrage V. - Entomologische Berichten, Amsterdam 8: 527-530.

Meijere, J.C.H. de, 1947. De Nederlandsche Entomologische Vereeniging bestaat 100 jaren, maar is nog jeugdig van geest en nog steeds bloeiend. - Tijdschrift voor Entomologie 88: 1-18.

Oudemans, A.C., 1926. Kritisch historisch overzicht der Acarologie. Eerste gedeelte, 850 v. C. tot 1758. - Tijdschrift voor Entomologie 69 (Suppl.): 1-500.

Oudemans, A.C., 1929a. Kritisch historisch overzicht der Acarologie. Tweede gedeelte, 1759-1804. - Tijdschrift voor Entomologie 72 (Suppl. I): 1-448.

Oudemans, A.C., 1929b. Kritisch historisch overzicht der Acarologie. Tweede gedeelte, 1759-1804. - Tijdschrift voor Entomologie 72 (Suppl. II): 449-784.

Oudemans, A.C., 1929c. Kritisch historisch overzicht der Acarologie. Tweede gedeelte, 1759-1804. - Tijdschrift voor Entomologie 72 (Suppl. III): 785-1097.

Piepers, M.C., 1912. In memoriam P. C. T. Snellen. - Tijdschrift voor Entomologie 55 (1/2): 1-8.

Piepers, M.C. \& P.C.T. Snellen, 1910-1913. The Rhopalocera of Java, 4 vols. Martinus Nijhoff, The Hague.

Roo van Westmaas, F.A. de, 1869. Repertorium der acht eerste jaargangen (1e Serie 1858 tot 1865) van het Tijdschrift voor Entomologie, uitgegeven door de Nederlandsche Entomologische Vereeniging. - Martinus Nijhoff, 's-Gravenhage. 40 pp.

Snellen, P.C.T., 1882. De vlinders van Nederland. 
Microlepidoptera, systematisch beschreven, 2 volumes. - E.J. Brill, Leiden. 1196 pp., 14 pls.

Snellen, P.C.T., 1900. Ter herinnering aan F.M. van der Wulp. - Tijdschrift voor Entomologie 43 (1/2): 1-11.

Terzo, M. \& P. Rasmont, 1998. Ceratina zwakhalsi et C. verhoeffi, deux nouvelles espèces de la region ouestpaléarctique (Hymenoptera, Apoidea, Xylocopinae). - Tijdschrift voor Entomologie 140 (2): 221-236.

Thompson, F.C., 2005. Biosystematic Database of World Diptera, Version 6.5... http://www.diptera.org/biosys. htm [visited on: 2007-10-30].

Wiel, P. van der, 1953. In memoriam Johannes Bastiaan Corporaal. 23 april 1880 - 28 mei 1952. - Tijdschrift voor Entomologie 96 (1/2): 1-7.

Wulp, F.M. van der, 1875. Repertorium betreffende den negenden tot en met den zestienden jaargang (2e Serie 1866-1873) van het Tijdschrift voor Entomologie, uitgegeven door de Nederlandsche Entomologische Vereeniging. - Martinus Nijhoff, 's-Gravenhage. 91 pp.

Wulp, F.M. van der, 1881. S.C. Snellen van Vollenhoven als entomoloog geschetst. - Tijdschrift voor Entomologie 24: lxxxix-cviii.

Wulp, F.M. van der, 1882. Repertorium betreffende deel XVII tot en met XXIV (3e serie, 1874-1881) van het Tijdschrift voor Entomologie, uitgegeven door de Nederlandsche Entomologische Vereeniging. - Martinus Nijhoff, 's-Gravenhage. 122 pp.

Wulp, F.M. van der, 1895. De Nederlandsche Entomologische Vereeniging. Geschiedkundig overzicht 18451895. - Martinus Nijhoff, 's-Gravenhage. iv, 99 pp.

Wulp, F.M. van der \& J.C.H. de Meijere, 1898. Nieuwe naamlijst van Nederlandsche Diptera. - Tijdschrift voor Entomologie 41 (Suppl.): 1-149.

\section{Editors}

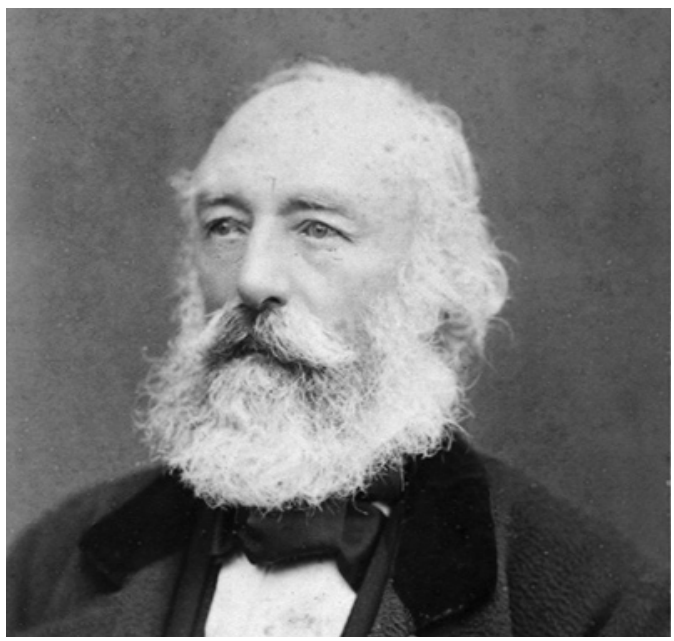

Fig. 13. S.C. Snellen van Vollenhoven, in his sixties, De Lavieter (archive naturalis).

\section{S.C. Snellen van Vollenhoven (1853-1880)}

Samuel Constant Snellen van Vollenhoven was born on 18 October 1816 in Rotterdam and died 22 March 1880 in The Hague. Although he studied law in Leiden to become a lawyer, he never practised and became the first Dutch professional entomologist instead. He was the first curator of Entomology at the "'s Rijks Museum van Natuurlijke Historie" in Leiden, where he was appointed in 1854 and worked until he left because of illness in 1873. Snellen van Vollenhoven was president of the NEV from 1845 to 1872 and again from 1878 till his death in 1880 . He was the driving force behind the publication of TvE, and acted as managing editor until his death. Apart from that, he published 87 papers on 1302 pages, and personally prepared 155 of the 277 plates that were published in the first
23 volumes. Several of his illustrations figure on the cover of this and the previous issue, and some examples of plates are presented elsewhere in this issue. Scientifically, Snellen van Vollenhoven laid the basis for the faunistics of most insect orders in The Netherlands, by compiling catalogues for several orders and for instance a long series of descriptions of the life history of sawflies (Hymenoptera: Symphyta). (biographies: Holthuis 1995, Krikken et al. 1981, van der Wulp 1881).

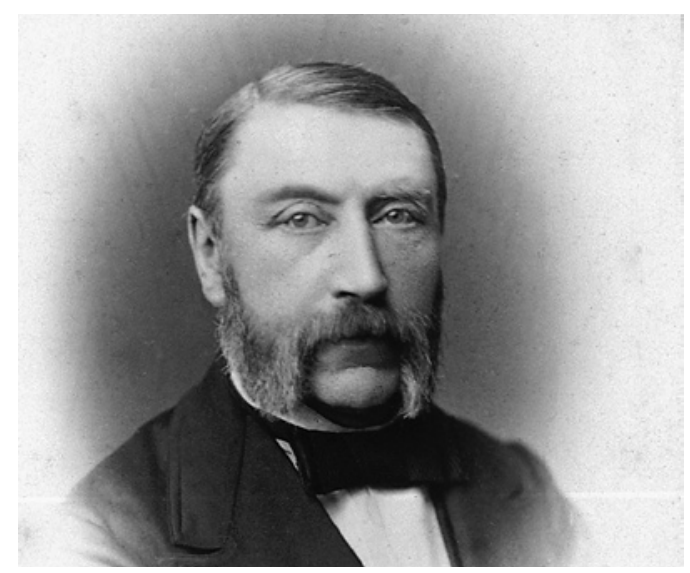

Fig. 14. F.M. van der Wulp, april 1878 (archives NEV).

\section{F.M. van der Wulp (1880-1894)}

Frederik Maurits van der Wulp was born in The Hague, 13th December 1818, as son of a civil servant. He himself also entered that profession, serving the General Auditor's office ("Algemene Rekenkamer"). He was one of the founders of the NEV, and decided early on to specialise on Diptera, because most other entomologists already worked on Lepidoptera and Coleoptera. He studied 
Diptera from all over the world, and also laid the basis for the Dutch faunistic studies of this order. He described an enormous number of taxa throughout the Diptera, many in the second Diptera volume of the famous Biologia Centrali-Americana. The online Diptera database (Thompson 2005) counts 1931 taxa described by van der Wulp. Apart from editor, van der Wulp also was secretary of the NEV during 25 years. Besides editing TvE, he was also responsible for writing the history of the NEV and two volumes of indexes (van der Wulp 1875, 1882, 1895). He died on 27 November 1899 (biography: Snellen 1900).

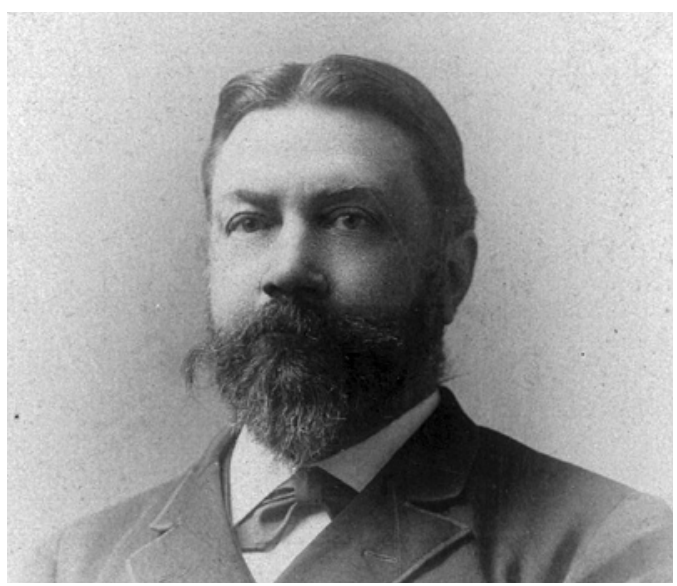

Fig. 15. A.F.A. Leesberg, ca 1880 (archives NEV).

\section{A.F.A. Leesberg (1894-1906)}

Antonius Franciscus Adolphus Leesberg was born on 22 November 1848 in The Hague and died on 8 December 1906 in The Hague. He did law studies at the University of Leiden, where he graduated with a thesis on Notarial acts. He got a position as notary in The Hague, succeeding his father, and also had political aspirations, as member of the city council. As an amateur entomologist, he devoted his time mostly to Coleoptera. He studied the Dutch beetles in close co-operation with Edouard Everts, the author of the three volume treatment 'Coleoptera Neerlandica'. (biography: Everts 1907).

\section{J.C.H. de Meijere (1906-1940)}

Johannes Cornelis Hendrik de Meijere was born 1 April 1866 in Deventer and died 6 November 1947 in Amsterdam. He studied biology in Amsterdam, and was curator at the Zoological Museum in Amsterdam from 1896 to 1921. In 1906 he was also appointed as university lecturer in the "Study on Arthropods", from 1908 as extraordinary professor in Technical Zoology and ordinary professor from 1921 on in the Applied Zoology and genetics, later also Entomology. He devoted most of his life to the study of Diptera, where he made a great impact on the faunistics of Dutch Diptera, the knowledge of the Oriental Diptera and

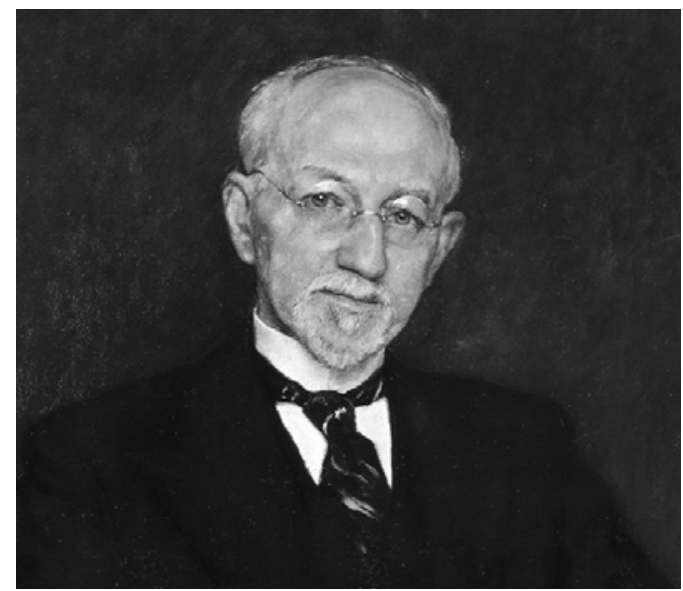

Fig. 16. J.C.H. de Meijere, 1932, after a painting by W.G. Hofker (archive Naturalis).

his studies on larvae of leafmining Agromyzidae. He served the NEV during a long time on the council, part of that as president. His devotion to TvE is unsurpassed with the 34 years he served as editor (biographies: Barendrecht 1948, Barendrecht 1949, De Jong 2000).

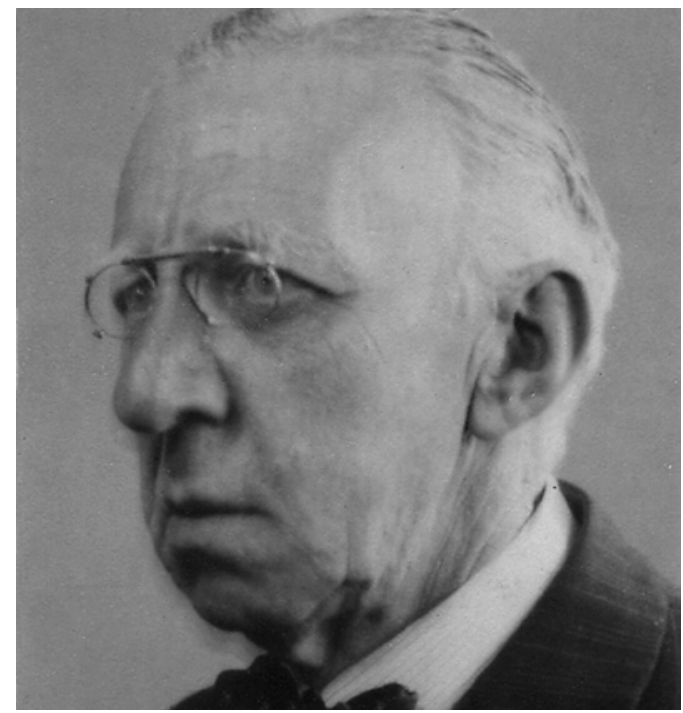

Fig. 17. J.B. Corporaal, as published by van der Wiel (1953) (archives NEV).

\section{J.B. Corporaal (1940-1952)}

Johannes Bastiaan Corporaal was born on 23 April 1880 in The Hague and died 28 May 1952 in Amsterdam. He studied at the Agriculture high school (now University) of Wageningen, and in 1903 he went to the Dutch East 
Indies to work in the tobacco plantations on Java and Sumatra, later also tea and rubber plantations. Since his school time he got interested in beetles and was a pupil of Edouard Everts. His combination of professional agronomist and amateur entomologist finally opened for him the possibility to become entomologist at the experimental station of the Rubber plantations in Sumatra from 1916 to 1921. Back in Holland, he succeeded De Meijere as entomology curator in the Zoological Museum in Amsterdam, where he stayed until his retirement. His scientific interest was mainly in the Coleoptera family Cleridae. He served a long time on the board of the NEV, especially as honorary secretary, and edited TvE until his death (biography: van der Wiel 1953).

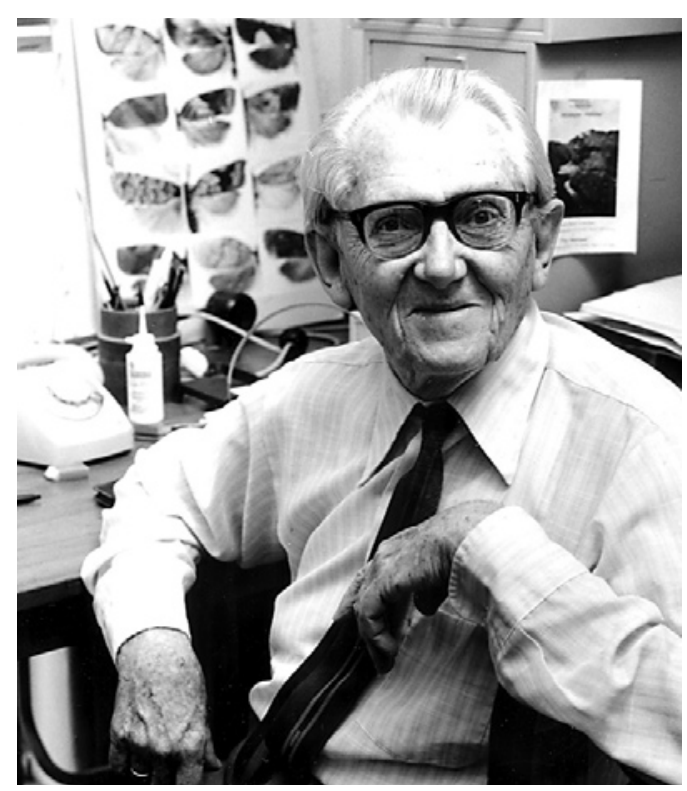

Fig. 18. A. Diakonoff in his office, during the 1980's. E. van Esch (archive Naturalis).

\section{A. Diakonoff (1952-1974)}

Alexey Diakonoff was born on 1 March 1907 in Sankt Peterburg and died 20 September 1989 in Leiderdorp. Shortly after the revolution of 1917 he fled Russia via Norway and in 1923 he was united with his parents, who had fled earlier, in the Dutch East Indies (now Indonesia). From there he studied biology in The Netherlands (Amsterdam) and graduated with a thesis on Indo-Malayan Tortricidae (Lepidoptera). After returning to Java he got a position at the research station of the sugar plantations and industries in Pasoeroean (Pasuruan, Java), and in 1941 as entomologist in the Zoological Museum of Bogor. During World War II he was imprisoned by the Japanese and after liberation returned to the Netherlands, until he took up his position in Bogor in 1947. In 1951 he returned to the Netherlands and became curator of Lepidoptera in the "Rijksmuseum van Natuurlijke Historie". After the death of J.B. Corporaal, Diakonoff was elected as managing editor from the last issue of volume 95 (1952). The changes he made in the journal were the largest since volume 1: meeting reports where no longer published, he reformed the style and the journal was transferred into a real international journal of Systematic Entomology. His editorship did not prevent him from writing numerous taxonomic treatments on Microlepidoptera, mostly Tortricidae and the Glyphipterigidae ‘sensu lato' (biographies: van Helsdingen \& van Nieukerken 1989; van Helsdingen 1990).

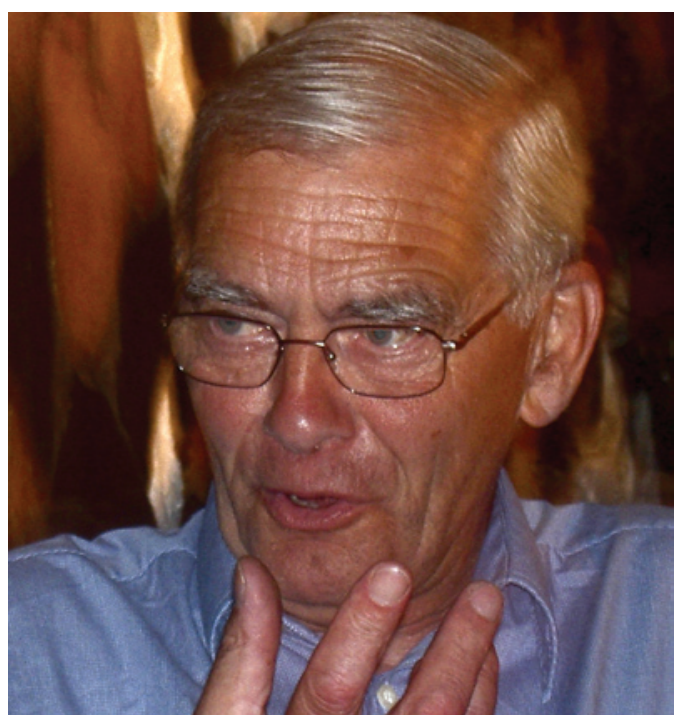

Fig. 19. P.J. van Helsdingen, 2002. Maker unknown.

\section{P.J. van Helsdingen (1975-1987)}

Peter Johan van Helsdingen was born 28 October 1934 in Soerabaja (former Dutch East Indies). He followed his study biology at the Leiden University and got a position as curator at the "Rijksmuseum van Natuurlijke Historie" in 1964. He was curator for the department of Diptera, and from 1983 onwards also of the department of Arachnoidea et al., but his research interest lay foremost with spiders, and he graduated on a thesis on the Linyphiidae (Araneae) in 1969. After returning from a year of study at the Museum of Comparative Zoology at Harvard, he became vicedirector of the museum. He then also became interested in the study of Dutch faunistics and introduced the idea of mapping the invertebrate fauna of The Netherlands according to the European Invertebrate Survey (EIS). He was instrumental in the appointment of the next two editors, both as coordinator for EIS-The Netherlands, and in this way also secured his successors as editor and as curator. Van Helsdingen is active on the board of EIS-The Netherlands and the international EIS to the present day. 


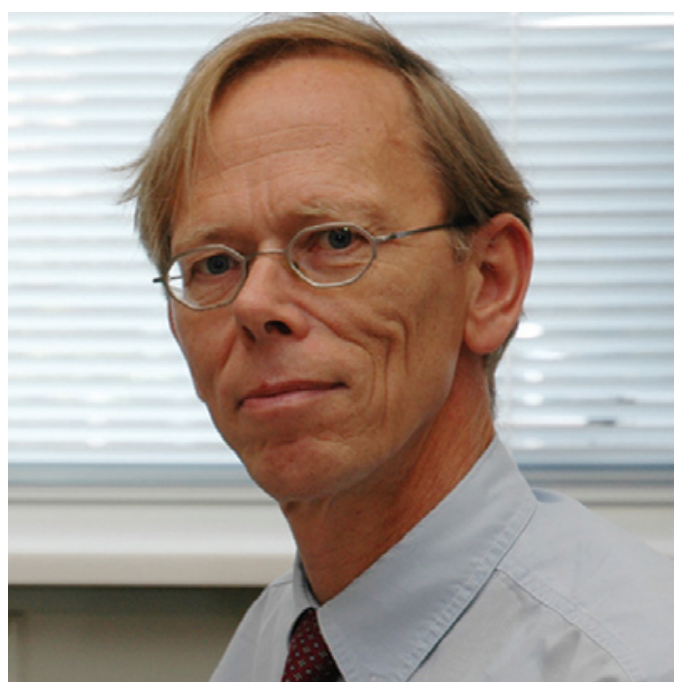

Fig. 20. J. van Tol, in his office, 2007, by C. van den Berg.

\section{J. van Tol (1988-1997)}

Jan van Tol was born in Rotterdam on 14 January 1951. In his youth he was a keen birdwatcher. During his biology studies in Leiden, and as a member of the Netherlands Youth Association for the Study of Nature, he got interested in aquatic insects, initially Hemiptera, later particularly Odonata. From 1977 to 1986 he worked as coordinator of the Netherlands Central Office of the European Invertebrate Survey (in the National Museum of Natural History), from 1986 he is research curator at the department of Entomology of the Leiden museum, and currently head of that department. His research centres around taxonomy, phylogeny and biogeography of South-East Asian Odonata, particularly Sulawesi, and the family Platystictidae. In this he follows the tradition of this museum, with his predecessors M.A. Lieftinck and D.C. Geijskes. Jan van Tol has been president of the NEV since 1998 and is commissioner of the International Commission on Zoological Nomenclature.

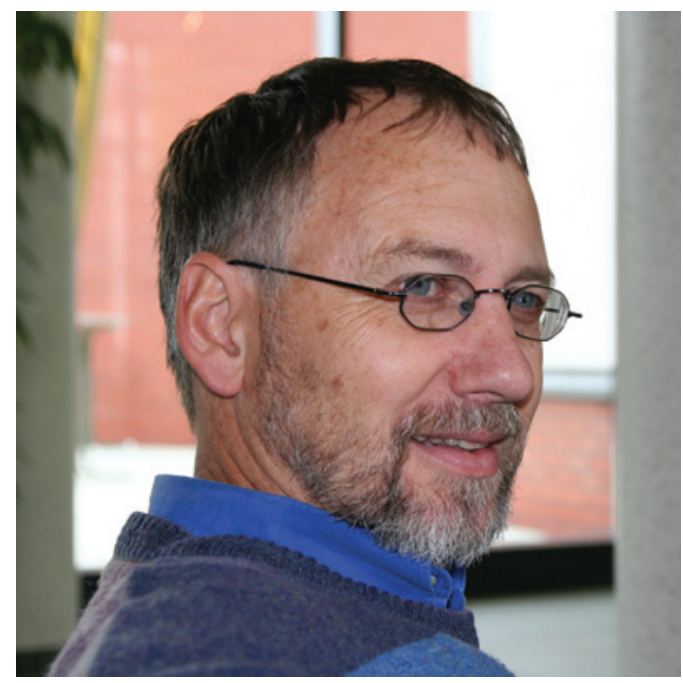

Fig. 21. E.J. van Nieukerken, 2007, during Lepidoptera congress in Erkner, Germany, by S. Richter.

\section{E.J. van Nieukerken (1989-2007)}

Erik Johannes van Nieukerken was born on 23 February 1952 in The Hague as son of a pianist. He got his interest in nature from his parents, and they also planted the seed of entomology by naming him after Godfried Bomans' novel "Erik, of het klein insektenboek" (Eric in the Land of the Insects). He studied biology in Leiden and also joined the Netherlands Youth Association for the Study of Nature, where he got interested in aquatic insects likewise as Jan van Tol, with special emphasis on diving waterbeetles (Dytiscidae). Jan and Erik worked frequently together, i.e. during their study they jointly made inventories of the Dutch aquatic macro invertebrates. From 1978 to 1983 Erik worked at the Free University Amsterdam on his thesis on Taxonomy of Nepticulidae (Lepidoptera), and graduated in 1986. In 1986 he was also appointed in the National Museum of Natural History as successor of Jan in the role as coordinator of the Netherlands Central Office of the European Invertebrate Survey. In the late nineties he also initiated and edited the book series "Nederlandse Fauna”. From 2000 he is science curator, with Lepidoptera and Arachnida as curatorial responsibilities, as successor both of Peter van Helsdingen and Alexey Diakonoff, and continuing research on systematics and phylogeny of Nepticulidae. 